\title{
Intellectual property in global software development: risks, laws and strategies in
}

\section{BRICS and Brazil}

\author{
Propriedade Intelectual no desenvolvimento global de software: riscos, leis e estratégias no BRICS \\ e no Brasil
}

Propiedad intelectual en el desarrollo global de software: riesgos, leyes y estrategias en BRICS y

Brasil

Received: 12/19/2020 | Reviewed: 12/26/2020 | Accept: 12/27/2020 | Published: 01/02/2021

\author{
Estelamaris da Costa Pina \\ ORCID: https://orcid.org/0000-0001-5475-157X \\ Universidade Federal de Sergipe, Brazil \\ E-mail: estela@ufs.br \\ Renata Silva-Mann \\ ORCID: https://orcid.org/0000-0001-5993-3161 \\ Universidade Federal de Sergipe, Brazil \\ E-mail: renatamann@academico.ufs.br
}

\begin{abstract}
The objective of this work was to point out risks, laws, solutions, and strategies for the protection of Intellectual Property in Global Software Development in BRICS and to identify the bottlenecks of this service, with focus in this service in Brazil. The work was carried out in three stages: (a) a literature review was systematized on Global Software Development Offshore Outsourcing (DGSOO); (b) evaluation of legislation of personal data and software protection; (c) survey with specialists of the Information Technology companies in Brazil. Companies that operate offering this service are usually located in different countries with different law and procedures, and this makes the service of risk for intellectual property rights. The group BRICS is involved in this type of service. However, the challenge for this type of service is to maintain gains without losing the intellectual property rights protection. Due to the ubiquitous nature of software in today's business environment, a DGSOO project needs to have its intellectual property protected, so that the risks of failure are minimized, and the benefits achieved. The greatest occurrences were found for the capacity to develop DGSOO projects and contracts, evidenced by the percentage of contracts finalized with delivery. Most contracts cover intellectual property clauses. The projects are mostly contracted in the software analysis stage and with confidential information, and yet $26.3 \%$ of contracts have problems with 1 to 10 projects per year; $5.3 \%$ have problems in 11 to 50 projects per year.
\end{abstract}

Keywords: Distributed software development; Outsourcing offshore; Data protection.

\section{Resumo}

O objetivo deste trabalho foi apontar riscos, legislação, soluções e estratégias para a proteção da Propriedade Intelectual no Desenvolvimento Global de Software no BRICS e identificar os gargalos desse serviço, com foco neste serviço no Brasil. O trabalho foi realizado em três etapas: (a) foi sistematizada uma revisão da literatura sobre terceirização de Desenvolvimento Global de Software (TDGS); (b) avaliação da legislação de proteção de dados pessoais e software; (c) levantamento com especialistas de empresas de Tecnologia da Informação do Brasil. As empresas que operam oferecendo este serviço geralmente estão localizadas em diferentes países com diferentes leis e procedimentos, o que torna o serviço um risco para os direitos de propriedade intelectual. O grupo BRICS está envolvido neste tipo de serviço. Porém, o desafio desse tipo de serviço é manter os ganhos sem perder a proteção dos direitos de propriedade intelectual. Devido à natureza onipresente do software no ambiente de negócios atual, um projeto TDGS precisa ter sua propriedade intelectual protegida, de forma que os riscos de falha sejam minimizados e os benefícios alcançados. As maiores ocorrências foram encontradas para a capacidade de desenvolvimento de projetos e contratos da TDGS, evidenciada pela percentagem de contratos finalizados com entrega. A maioria dos contratos cobre cláusulas de propriedade intelectual. Os projetos são em sua maioria contratados na fase de análise de software e com informações sigilosas, porém $26,3 \%$ dos contratos apresentam problemas entre 1 a 10 projetos por ano; $5,3 \%$ têm problemas entre 11 a 50 projetos por ano.

Palavras-chave: Desenvolvimento de software distribuído; Terceirização offshore; Proteção de dados.

\section{Resumen}

El objetivo de este trabajo fue señalar riesgos, legislación, soluciones y estrategias para la protección de la Propiedad Intelectual en el Desarrollo Global de Software en BRICS e identificar los cuellos de botella de este servicio, 
enfocándose en este servicio en Brasil. El trabajo se llevó a cabo en tres etapas: (a) se sistematizó una revisión de la literatura sobre la subcontratación del Desarrollo Global de Software (TDGS); (b) evaluación de la legislación sobre protección de datos personales y software; (c) entrevista a especialistas de empresas de Tecnología de la Información en Brasil. Las empresas que operan ofreciendo este servicio generalmente están ubicadas en diferentes países con diferentes leyes y procedimientos, lo que hace que el servicio sea un riesgo para los derechos de propiedad intelectual. El grupo BRICS está involucrado en este tipo de servicio. Sin embargo, el desafío para este tipo de servicio es mantener las ganancias sin perder la protección de los derechos de propiedad intelectual. Debido a la naturaleza ubicua del software en el entorno empresarial actual, un proyecto TDGS debe tener su propiedad intelectual protegida, de modo que se minimicen los riesgos de falla y se logren los beneficios. Las mayores ocurrencias se encontraron en la capacidad de TDGS para desarrollar proyectos y contratos, evidenciada por el porcentaje de contratos finalizados con la entrega. La mayoría de los contratos cubren cláusulas de propiedad intelectual. La mayoría de los proyectos se contratan en la fase de análisis de software y con información confidencial, sin embargo, el 26,3\% de los contratos tiene problemas con 1 a 10 proyectos por año; El 5,3\% tiene problemas en 11 a 50 proyectos al año.

Palabras clave: Desarrollo de software distribuido; Subcontratación offshore; Protección de datos.

\section{Introduction}

In a global service-based economy, outsourcing has become a practice and is the choice of many well-organized companies. The economic benefits of structured outsourcing services are specialized efficiency in earnings and positive costbenefit rates. In most cases are due to international labor and environmental standards and corporate codes of conduct could mitigate some of the most intense concerns raised about offshoring but offshoring is likely to present challenges to societies, corporations, and stakeholders for many decades labor (Doh, 2005). Generally, the need to access qualified personnel are important explanatory factors for offshoring innovation decisions. The location of the host country, its expertise and familiarity with the required language is important, in addition to its culture and the existence of the specialized service (Lewin et al., 2009; Doh, 2009; Zaheer et al., 2009).

The main outsourcing operations in Information Technology (IT) are call centers; web services; software development where a new system is developed; and maintenance, where they can be repaired, adapted, or extended (Wiederhold et al., 2010).

When organizations transfer all or part of their software development offshore outsourcing, at a low cost where technical skills are more available, is acting as a consumer; and the service provider will be responsible for software development (Verner, 2014).

Software development projects are almost always collaborative and distributed. Distributed software development (DSD) is one of the services practiced in offshore IT outsourcing, where activities are distributed by teams in different geographic regions. The work is progressed to an open platform for software development, using communication technologies, to interrelate software development projects, which are integrated into shared projects.

When development takes place in different countries, it is called Global Software Development (GSD). This scenario consists of a complex system, in which teams located in various parts of the globe and in different regions and exists a local time collaboration to produce software (Casey, 2008).

Companies choose Global Software Development Offshore Outsourcing (GSDOO) for low cost and product quality (Niazi, 2016). Companies located in developed Western countries seek emerging markets, such as China and India (Soderberg; Romani, 2017). India's IT sector began to grow in the late 1950s. One of the most important IT services companies in India is Tata Consultancy Services (TCS). It is present in 42 countries and allows India to occupy its position in the global market. The main reason for continued growth is the quality of services. In addition, there is constant investment in research and development (R\&D) (Mathur; Khurana, 2013).

China has become a destination of GSDOO, mainly due to the increasing government investment in IT infrastructure. Its services are relatively cheapest in the world. However, to attract more customers, China needs to elevate intellectual 
property rights (IPR) protection based on training professionals with English proficiency, business and project knowledge, leadership, and communication skills (Jones, 2009).

Brazil emerges as a global provider of IT services, but is still a small service provider, but has a strong national customer base. However, according to the Brazilian Association of Information and Communication Technology Companies, there is a strategic intention for GSDOO. This fact is confirmed by the Global Services Location Index - GSLI, which identifies countries that provide IT services (A.T. Kearney, 2019).

Software is an intangible asset, and allows differentiation, which represents a competitive advantage in the market. These assets, including IPR, that can be a critical element in a successful economy. For this reason, IP management is important for the growth and strengthening of companies and national economies (Wipo, 2018). The types of IP are the design specifications; the user manual; the software offshoring; the software for supplier development; the database; the process descriptions; and the instructions transmitted with confidence, which provide an unquestionable understanding of the primary material. If the company also sells products in the foreign geographic area, its knowledge will include the rights of trademarks; along with the products describing; the business methods; and instructions on how to explore the market negotiations (Wiederhold et al., 2010; Gupta, 2017).

GSD IP differs depending on the level of outsourcing. In Outsourcing 1.0, the model is based on the expansion of the team, with technical specifications and are required to work under the command of the client (internally). The Outsourcing 2.0 is based on the delivery of the product and the command that is the responsibility of the contractor (supplier). Finally, Outsourcing 3.0 is the product developed in partnership with customer and supplier at the same time. There is a firm commitment from both managers on both sides. When outsourcing, the participants are not only companies, but also the host countries and their respective laws (Soderberg; Romani, 2017).

In GSDOO exist several challenges, meanly for IPR. IP sharing between the company and the customer is preexisting. Companies share their trade secrets, know-how and business plans, resulting in a possible consequence of the loss of IP. There may be adverse effects on customer profitability, brand image and company advantages. One of the risks was the misappropriation of IP (Gupta, 2017). The motivation for this work is to identify the challenges that still exist for DSGOO. It became necessary to identify and manage the risks associated with this outsourcing.

Typical challenges for organizations can be: (a) supplier access to the server, especially when the company has technical data controlled by the state; (b) critical data such as source code, which needs to be shared for development or maintenance; (c) the lack of control over the supplier's IP protection infrastructure; (d) the lack of awareness among the supplier's employees; (e) the supplier's employees who are hired by a competing organization; (f) and the reuse of parts of the code that were used directly or indirectly in other clients' projects (Pai, Basu, 2007).

The customer and the service provider may have different expectations about IP and the willingness to share rights can vary considerably. Therefore, some IP problems need to be negotiated before establishing a customer/supplier relationship. These problems include refinements or modifications that will result in co-authorship; jointly owned creations, or adaptation (derivative work). Another aspect to consider is the property, which should be defined as a single part or a whole. It must also be considered which rights each party will exploit in the jointly created IP. Finally, what will happen to the customer's PI when he wants to change the project (Pai, Basu, 2007).

Critical factors for GSDOO were identified in the literature, such as culture, language, difference of time in countries, organizational management, environmental management, communication facility, knowledge transfer, project definitions, and team specifications. The categories of the critical factors can be classified in order of importance in accord with organizational levels (customer and supplier), projects, cultural and environmental issues. The most critical factors for software projects, regardless of category, are team trusty, efficient communication skills, cultural empathy, customer- supplier relationship, the 
type of contract and the efficiency to transfer of knowledge. Thus, IPR is part of organizational category (Sudhakar, 2013).

The cooperation among the BRICS IP offices aims at enhancing the value of IP and to ensure its contribution to the economic development and growth in the member countries. The cooperation was originated from the 2012 BRICS Heads of IP offices meeting in Geneva, Switzerland. The BRICS are a strategic group since they combine a set of privileged characteristics around their geographical location. In addition, there are countless natural resources available; and the instigating operational capacity of economic potential; and their influence on political leadership in the respective regional areas (Benachenhou, 2013). In 2013, the cooperation model was adopted in the block that establishes project flows, such as: personnel training; IP strategy and public awareness; IP information service, among others (IPBRICS, 2019).

There is constant concern about IPR and the establishment of metrics and indicators such as the GSLI that are relevant aiming the legal security business relationship in GSDOO. Given the importance of the topic, it is necessary to analyze the legal structures of IPR related to GSDOO in the context of copyright, specifically the protection of software, databases, and personal data. For this study, the legal documents in BRICS were chosen to establish a comparative framework. GSDOO presents country-related instabilities and a lack of IPR could be a problem to be solve. Thus, the objective of this study was to identify risks, challenges, and strategies in relation to the protection of IPR in GSDOO.

\section{Methodology}

This work is based on the type of exploratory research with a quantitative and qualitative approach and its nature is applied. The work was carried out using three stages, in the first a systematic review was carried out on the GSDOO theme; in a second stage the legislation on data and software protection in BRICS countries were evaluated and in the third stage a questionnaire with IT specialists was obtained, aiming to identify companies working in GSDOO in Brazil and to identify how IPR has been treated. In Table 1 there are the steps and procedures used in study of IPR in GSDOO.

Table 1. Procedures in the study on Global Software Development Offshore Outsourcing (GSDOO).

\begin{tabular}{|c|l|l|l|}
\hline N & \multicolumn{1}{|c|}{ Steps in a Systematic Review } & \multicolumn{1}{|c|}{ Actions } \\
\hline 1 & Identify of GDSOO and determine the questions & Write a plan for the review (protocol) \\
\hline 2 & Search for studies, Select studies for inclusion based on pre-defined criteria & Define inclusion and exclusion criteria \\
\hline 3 & Extract data from included studies & Identify your research questions \\
\hline 4 & Assess the quality of studies, Evaluate the risk of bias of included studies & Combine the data Overall findings \\
\hline 5 & Identification & Critical factors, risks, solutions, Strategies & \multicolumn{2}{|l|}{ Tools } & TI specialists \\
\hline 6 & Systematic review & \multicolumn{2}{|c}{ Resulting } \\
\hline 7 & \multicolumn{2}{|l}{} \\
\hline 8 & Intellectual Property Rights Protection + BRICS +Global Software Development & \\
\hline
\end{tabular}

Source: Authors.

In Table 1 there are presented the stages of the research. In stage 1 it was identified the mean questions to be researched on GDSOO. In stage 2, 3 and 4 the studies in literature were searched and selected. The mean data extracted and verified the quality of studies, as well the risk of bias of included studies. In stage 5, 6 and 7 the mean findings were listed. In stage 8 all contributions were interconnected on GDSOO.

The systematic review was carried out using five main steps: planning; the database searching; literature selection, data mining, comprehensive literature analysis; and, finally, the strategies identification. The systematic review planning is described in Table 2 . 
Table 2. Planning for the systematic review of Global Software Development Offshore Outsourcing (GSDOO).

\begin{tabular}{ll}
\hline \multicolumn{1}{c}{ Issue } & \multicolumn{1}{c}{ Description } \\
\hline Questions & $\begin{array}{l}\text { What is reported in the literature on Intellectual Property Protection (IP) for global software development } \\
\text { (DGS) between } 2008 \text { and } 2018 ?\end{array}$ \\
\hline Keywords & $\begin{array}{l}\text { "Distributed software development AND India/Russia/China/Brazil/Africa)" } \\
\text { "Global software development AND India/Russia/China/Brazil/Africa)" } \\
\text { "Global software development OR distributed software development AND intellectual property }\end{array}$ \\
\hline $\begin{array}{l}\text { Data Base } \\
\text { documents }\end{array}$ & CAPES, SciELO, Web of Science, Scopus \\
\hline $\begin{array}{l}\text { Framework } \\
\text { timeline }\end{array}$ & Scientific publications \\
\hline
\end{tabular}

Source: Authors.

In Table 2 are presented the questions, keywords, data base, type of documents, and framework timeline of the planning for systematic review.

The data from the systematic review on Global Software Development Offshore Outsourcing is presented in Table 3.

Table 3. Data from the systematic review of Global Software Development Offshore Outsourcing (GSDOO).

\begin{tabular}{ccc}
\hline \multicolumn{3}{c}{ Database Search } \\
\hline Keywords & $\begin{array}{l}\text { Number of scientific } \\
\text { publications }\end{array}$ & $\begin{array}{l}\text { Number of Publications without duplication by } \\
\text { keyword }\end{array}$ \\
\hline $\mathbf{1}$ & 293 & 279 \\
\hline $\mathbf{2}$ & 387 & 65 \\
\hline $\mathbf{3}$ & 66 & 715 \\
\hline Total & 746 & 172 \\
\hline $\begin{array}{c}\text { Duplication of publications by } \\
\text { keywords }\end{array}$ & & 65 \\
\hline
\end{tabular}

\section{Total of publications}

543

Source: Authors.

The systematic review totaled 715 articles, 172 were identified as duplicates, with 543 publications remaining to proceed the articles selection (Table 3). In the second stage of the research, legislation, and frameworks for IPR were evaluated in the Lex WIPO database (laws and agreements) for each country of the BRICS. In a complementary systematic review, publications from the Brazilian Institute of Information in Science and Technology - IBICT and legal sites were consulted, to reach the legal instruments of the BRICS. The qualitative data that characterize the countries' legislation was systematized to identify similarities and differences.

Finally, IT specialists were questioned about GSDOO in Brazil to identify companies' practices in IPR related to GSDOO.

The specialists were assessed by a structured questionnaire with pre-formulated questions categorized into 2 dimensions, 11 questions of demographic dimension and 18 questions of the intellectual property dimension. The questionnaire 
survey was applied to specialists in companies of GSDOO. 133 IT companies were contacted initially by contact by telephone. Additionally, IT individual researchers were also contacted between June and July 2020.

\section{Results and Discussion}

\subsection{Systematic review}

The selection in the literature was carried out by title and abstracts resulting in a classification in GSDOO (typology) (Table 4).

Table 4. Selection of articles in a systematic review on Global Software Development Offshore Outsourcing (GSDOO).

\begin{tabular}{|c|c|c|c|}
\hline Typology & Description & Criteria & Number \\
\hline Out of Context & Articles that not mentioned GSD or DSD & exclusion & 257 \\
\hline Management & GSD/DSD management & inclusion & 213 \\
\hline Process & Software development process GSD/DSD & inclusion & 57 \\
\hline Human Resources & Staff issues & inclusion & 11 \\
\hline Case Study & GSD/DSD & inclusion & 5 \\
\hline Total inclusion & & & 286 \\
\hline
\end{tabular}

Source: Authors.

In Table 4 it is presented the typology, description, criteria and number of articles identified on GSDOO. There were identified 257 Articles that not mentioned Global Software Development (GSD) or Development of Software Distributed (DSD). In this sample of articles 11 addressed about human resources (staff issues) and 5 GSD/DSD.

Subsequently, data mining was carried out in 286 publications. This step resulted in 35 articles for comprehensive analysis. It was also included articles cited before 2008. The studies were grouped according to their contribution to IPR in GSDOO (Figure 1).

Figure 1. Publications classified as contribution to Intellectual Property Rights in Global Software Development Offshore Outsourcing (GSDOO).

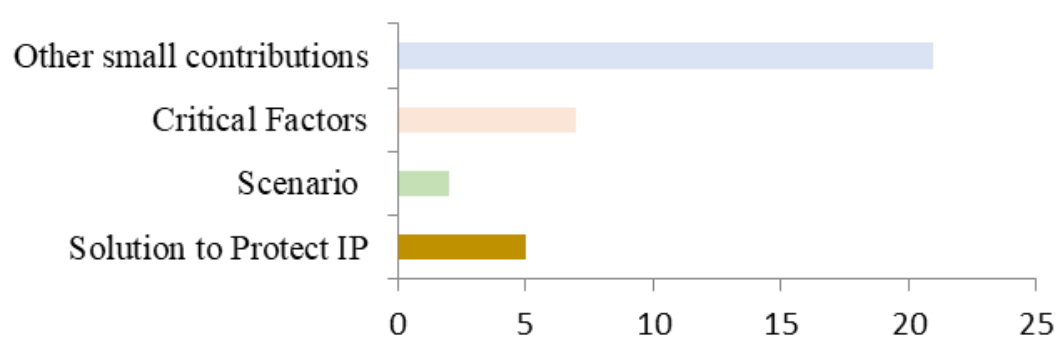

Source: Authors.

In Figure 1, 5 articles presented IPR solutions; 7 presented critical factors for GSDOO, 2 presented the scenario of GSDOO and 21 other small contributions. It was observed that there is a failure in contracts due to the lack of legal planning. Adjustments to IPR have been proposed. The first concern that was raised and presents a risk in contracts abroad was the IPR. Various types of IP assets can be involved in offshore outsourcing relationships. A challenge in this offshore scenario is that each contract is regulated by a specific type of law for each country involved. Consequently, there are added complexities 
related to management if the partners are from different countries. The contract must be detailed to deal with IPR problems during and after the service.

There are several possible strategies for sharing IPR between the customer and the supplier. The concern is the inadvertent, accidental, or intentional disclosure of confidential information and trade secrets. In many countries, trade secrets are inadequately protected by specific national laws and therefore need to be explicitly protected by an express contract and a confidentiality agreement. The customer and the supplier may have similar financial expectations, but the willingness to share parts of that IPR can vary considerably. Therefore, each party must define which IPR assets to keep out of the contract and which to share. Appropriate measures are needed to safeguard the interests of consumers and businesses, through IPR protection, requiring more universal and stricter legislation (Pai, Basu, 2007).

The need for an IP assessment, specifically for software, is proposed since it is easy to replicate. The effects of a risk of loss of IP can only be quantified if evaluated, for this the intellectual and monetary transfer of capital must be considered. Development of Software operations require IP, and the export of the service must be evaluated and becomes a taxable profit.

In the case of tax havens, the situation has become even more complex due to regulations. Thus, an evaluation model to measure IP transfer should be considered when incorporated into the software. And when it occurs abroad, labor rates, product prices, sales volume, available IPR and tax regulations must be considered (Wiederhold et al., 2010).

In companies that practice open innovation, IPR protection is often abdicated. Consequently, there may be conflicts with the partners for this jointly created appropriation. In this scenario, the concept of modularity adjustment, as the modular structure of a system allows to reconcile the opportunities for distributed innovation. To optimize the capture of the value of a new product or process, it is necessary to manage the IP of the artifact and its modular structure of the system. For securityessential products, modules can be segregated according to security certification levels. Classified data can be stored and processed separately from unclassified data. Therefore, there is a technical level of solution that has not been contextualized for GSD / DSD (Henkel et al., 2013). An example is India's IT industry that becomes an important global offshore center. The major challenges reported for this country are the creation and adaptation to an outsourcing model from the supplier's perspective, for projects with higher added value. Thus, it is necessary to consider the quality of the service, the shared security of knowledge. The contract must be comprehensive with clauses, since an eventual need, intervention by legal process will not be necessary. The suggestion is to create policies and a regulatory environment, aiming to assist in this sustainability (Mathur, Khurana, 2013). Finalizing the solutions, a contractual model is proposed to manage the risks associated with outsourcing, due to the misappropriation of IPR and the escape routes of service providers. As suggestion the proposal is to establish a model based on planning, implementing an incentive strategy and less knowledge sharing (between the customer and the supplier). The contract must be based on results to ensure that the appropriate incentive exerts the ideal effort on outsourcing. It can be considered as a strategy to increase the cost of outsourcing. Therefore, the profits for the supplier would be higher, due to the inefficiency associated with the internal organization. Therefore, from the customer's point of view, it is attractive to choose satisfactory reliable IPR outsourcing locations. The presence of an innovative solution is important, based on the encouragement of good practices and with financial incentives for the customer and the supplier, without necessarily considering these solutions through international regulations or through extensive contracts (Gupta, 2017). The challenges are also pointed out in the literature and the opportunities of the offshore centers in China, as a potential cost reduction advantage, with a large market. This opens markets for Chinese in Asia. China's software industry is also acquiring domestic demand for its IT services. But the caution is that China still needs to gain confidence by exhibiting much more stringent IPR protection. In addition, software workers must have profound English proficiency and good business knowledge. With government investments in IT infrastructure and additional training in English. Customers can also prevent loss of knowledge by outsourcing by offering a career path to their employees (Jones, 2009). 
Other important points of verification are the laws on electronic commerce. As an example, the agreement with the United Nations Conference on Trade and Development (UNCITRAL) can be mentioned, if the country is a signatory to the Berne Convention and the Council of Europe Convention on Cybercrime (COE); whether a democracy was adopted; and, finally, whether they included security indicators for the country of origin, as well as factors such as language and country time difference. Companies are likely to have their IT services investments in countries with little protection for their IPR. However, the experience and familiarity with institutions that work in IPR, like those in the host country, moderated this effect. Therefore, there is a complex model for assessing whether countries that are developing their activities abroad are focused on subsidiary companies (Jandhyala, 2013). Thus, it is necessary to consider the size of the company and its critical factors. For small and medium-sized companies (SMEs), factors related to human resources can be found; technical infrastructure; customer interface; commercial infrastructure and the regulatory interface. In addition to these critical factors such as worker skills, customer knowledge, trust in outsourcing, telecommunications and IPR protection. Factors related to infrastructure and IPR are poorly explored, as they affect startups. SMEs need to ensure that the customer's IP is respected and protected. However, these companies cannot create regulations to protect IP if these regulations do not exist in their countries. SMEs need their governments to be able to ensure the use and enforcement of IP protection laws (Jennex, Adelakun, 2003). In addition to the bottlenecks presented, there are critical barriers to outsourcing, such as: difficulties in communication; political and economic instability in the country; delays in service delivery; the existence of hidden expenses; incompatibility with the customer; the lack of management; the lack of technical capacity; the poor quality of services; opportunistic behavior; poor contract management; and strategic inflexibility. The companies most impacted by the lack of IP protection are small, since medium and large companies establish best practices for protection. Thus, attention should be focused on the country's instability barrier that is often cited, together with the barrier due to lack of IP protection (Khan et al., 2011).

A risk assessment methodology was developed to be used in offshore outsourcing contracts. The methodology aimed to classify 11 risks and their impacts, they are: the strategy, the business, the technical, the financial, the legal, the operational, the environmental, the information, the managerial, the relationship and the time of management. When assessing legal risk, four items are presented that must be analyzed, as they influence the outcome of this risk, they are: the differences in rules and regulations in global negotiations; the lack of customer experience in outsourcing; issues related to privacy, piracy and security; and uncertainty about the legal environment (Samantra et al., 2014). Twelve factors were identified that influence the allocation of tasks in software projects, and two project management models were considered, the centralized and the distributed. In the centralized management model, the factors that most influence are the cost of resources and the dependence on tasks. In the distributed model, project managers are more concerned with the size of the task. It is concluded that there is little difference between the structures of centralized and distributed project management regarding the allocation of tasks of the software project. IP is presented as an influencing factor in the allocation of tasks, although it is low (Niazi, 2016). IPR and its protection is addressed without significant contributions in the literature, however, some knowledge engineering practices (Parviainen, Tihinen, 2014); GSD governance in transactional memory systems and asset management are reported (Manteli, 2014) (Bookhamer, Zhang, 2016). In Table 5 there are fragilities, solutions and strategies in GSDOO aiming to access the IPR protection. 
Table 5. Fragilities, Solutions and Strategies in GSDOO.

\begin{tabular}{|c|c|c|}
\hline Fragilities & Solutions & Strategies \\
\hline $\begin{array}{l}\text { (a) The lack of legal planning of the intellectual } \\
\text { property rights in contracts. } \\
\text { (b) Accidental or intentional disclosure of } \\
\text { confidential information. } \\
\text { (c)The commercial infrastructure and the } \\
\text { regulatory interface. } \\
\text { (d) Communications gap - language. } \\
\text { (e) Economic instability in the country. } \\
\text { (f) Service delivery delays. } \\
\text { (g) The lack of project management. } \\
\text { (h) The lack of Intellectual Property Rights } \\
\text { Protection (IPR). } \\
\text { (i) The lack of technical capacity. } \\
\text { (j) Cultural barriers. }\end{array}$ & $\begin{array}{l}\text { (a) Contract flexibility. } \\
\text { (b) Sharing of the IP } \\
\text { rights. } \\
\text { (c) Confidentiality } \\
\text { agreement. } \\
\text { (d) IPR protection. } \\
\text { (e) Risk of the loss of IP } \\
\text { quantified. }\end{array}$ & $\begin{array}{l}\text { (a) Universal and rigorous legislation. } \\
\text { (b) The intellectual and monetary transfer of } \\
\text { capital must be considered. } \\
\text { (c) Models to measure the IP transfer. } \\
\text { (d) The modular system architecture. } \\
\text { (e) Country's national legislation, adding } \\
\text { complexities to the management. } \\
\text { (f) Specific national laws. } \\
\text { (g) Regulatory practices to support } \\
\text { globalisation. } \\
\text { (h) More universal and rigorous legislation. } \\
\text { (i) An evaluation model to measure the IP } \\
\text { transfer. } \\
\text { (j) Policies and a regulatory environment. }\end{array}$ \\
\hline
\end{tabular}

Source: Authors.

In Table 5 there were identified 10 fragilities, 5 solutions and 10 strategies on GSDOO for IPR. Technical solutions for IP protection at the project level are identified as data masking (cryptography) and as software architecture, which keeps the IP in part of the isolated code. The solutions aimed at adapting to legal instruments are the most delicate, because the projects are in different countries, each with its own legislation. The Confidentiality Agreements (NDA) recommended along with physical and logical security controls are also identified as a solution. It is also suggested in the literature to establish and seal IP inventory, before signing any new contract. This document could support customer and supplier estimates and expectations, identifying existing IP assets and software licenses.

\subsection{DGS-related legislation}

From the point of view of the legislation of the countries, there was an internationalization of national laws promoted by the principles and recommendations of the Berne Convention, WCT and TRIPS. However, when analyzing the year of creation of the copyright law of the BRICS countries and the year of the last update, it is observed that India was the first country in the bloc to have specific copyright legislation in 1957; and the last update in 1994, China and Russia in 1990 and 1992, respectively. Brazil and South Africa had their first laws in the same decade, in 1973 and 1978. South Africa has a modern version that is awaiting promulgation and Brazil updated its legislation in 1998.

International instruments related to copyright, such as the Berne Convention and WCT, are strongly related to Information Technology (IT) activities, since computer programs and databases are within the scope of protected works. Computer programs and databases are used as tools for software development, as they are also part of the product generated, which is, in most cases, a management, strategic or decision information system.

Personal data processed and stored in databases are also subject to protection. in this case, the most recent concern of the countries and whose guiding instrument is the General Data Protection Regulation No. 679 of the European Union of 2016. Table 6 shows data from the five BRICS countries, indicating the main international legal instruments related to copyright and dates of adherence to regulations in those countries. 
Table 6. Legal System of International Copyright Law.

\begin{tabular}{llllll}
\hline Country & Brazil & Russia & India & China & Soth Africa \\
\hline Berne Convention & 1922 & 1995 & 1928 & 1992 & 1928 \\
Signatary of WCT & - & 2009 & 2018 & 2007 & - \\
OMC member & 1995 & 2012 & 1995 & 2001 & 1995 \\
IP agency & INPI & ROSPATENT & CGPDTM & CNIPA & CIPC \\
Law (year) & 1998 & 1992 & 1957 & 1990 & 1978 \\
Transference & $1,2,3$ & 1,4 & 1 & $1,2,3$ & $1,5,2$ \\
Software protection & 1998 & 1992 & - & - & - \\
Protection (years) & 70 and $50^{*}$ & 70 e $50^{*}$ & 60 & 50 & 50 \\
\hline
\end{tabular}

Source: Authors.

In Table 6 the law framework from Brazil, Russia, India, China and South Africa are presented about Berne Convention, Signatary of WCT, OMC member, IP agency, Law (year), Transference, Software protection and Protection (years). Countries with a socialist or communist political history had more time to adhere to the Berne Convention, such as Russia and China. India has a more mature copyright law. Brazil, India and South Africa have been members of the General Agreement on Tariffs and Trade (GATT) since 1948. Therefore, they participate in the rounds of discussions and in the elaboration of the TRIPS Agreement and, consequently, of the World Trade Organization (WTO) in 1994, becoming members in 1995, when it was consolidated. Russia and China became members of the WTO in 2012 and 2001, and did not participate in the negotiations. Brazil and South Africa are not signatories to the WCT. However, countries recommend a minimum of 50 years for the protection of computer programs. The legislation of the BRICS countries in relation to copyright is in conformity with the Berne Convention for protection period, principle of automatic protection and limitation of protection. The Convention establishes that the period of protection of a work, as a rule, must be up to fifty years after the death of the author.

GDPR No. 679 requires that data controllers be complying and implement principles such as legally, fairly, and transparently processing data in relation to the data subject (transparency). In addition, they must collect data for specific, explicit, and legitimate purposes, e. The processing of these data must be compatible with the initial objectives (purpose limitation); adequate, relevant, and limited storage in relation to the purposes for which the data are processed (data minimization). In addition, measures must be taken to ensure that inaccurate personal data is erased or rectified without delay (accuracy). The data must be maintained in a way that allows the identification of the holders for a period not longer than necessary (storage limitation). As for security actions, personal data, including protection against illegal processing, loss, destruction or accidental damage, must be done using appropriate technical or organizational measures (integrity and confidentiality) (EU Publications Service, 2019). Guided by these principles, the data protection regulations of the five BRICS countries are shown in Table 7. 
Table 7. Data protection in the countries that make up the BRICS.

\begin{tabular}{|c|c|c|c|c|c|}
\hline & Brazil & Russia & India & China & South Africa \\
\hline Law & 2018 & 2006 & 2018 & 2020 & 2013 \\
\hline Regulator & $\begin{array}{l}\text { National Data } \\
\text { Protection } \\
\text { Authority } \\
\text { (ANPD) }\end{array}$ & $\begin{array}{l}\text { Federal Service for } \\
\text { Supervision of } \\
\text { Communications, } \\
\text { Information Technology } \\
\text { and Mass Media } \\
\text { (Roskomnadzor) }\end{array}$ & $\begin{array}{l}\text { Data Protection } \\
\text { Authority } \\
\text { (DPA) }\end{array}$ & $\begin{array}{l}\text { Standardization } \\
\text { Administration of China } \\
\text { (SAC) and the State } \\
\text { Administration for } \\
\text { Market Regulation } \\
\text { (SAMR) }\end{array}$ & $\begin{array}{l}\text { Regulator } \\
\text { Information }\end{array}$ \\
\hline Escope & $\begin{array}{l}\text { Companies that } \\
\text { offer services to } \\
\text { Brazil from data } \\
\text { collected in } \\
\text { Brazil }\end{array}$ & $\begin{array}{l}\text { Companies inside and } \\
\text { outside Russia that handle } \\
\text { Russian personal data }\end{array}$ & $\begin{array}{l}\text { In India and } \\
\text { abroad }\end{array}$ & In India & $\begin{array}{l}\text { People domiciled } \\
\text { or not in South } \\
\text { Africa, but using } \\
\text { processing in } \\
\text { Africa }\end{array}$ \\
\hline Subjects & $\begin{array}{l}\text { Holder, } \\
\text { controler, } \\
\text { operator, } \\
\text { supervisor and } \\
\text { treatment agent } \\
\text { (all involved). }\end{array}$ & Titular and operator & $\begin{array}{l}\text { Holder, data } \\
\text { processor and } \\
\text { fiduciary } \\
\text { (controller) of } \\
\text { data. }\end{array}$ & $\begin{array}{l}\text { Subject of Information, } \\
\text { Administrator, receiver, } \\
\text { third-party testing and } \\
\text { evaluation agency }\end{array}$ & $\begin{array}{lr}\text { Subject } & \text { of } \\
\text { Information and } \\
\text { Responsible }\end{array}$ \\
\hline $\begin{array}{l}\text { Data } \\
\text { category }\end{array}$ & $\begin{array}{l}\text { Personal and } \\
\text { sensitive }\end{array}$ & $\begin{array}{l}\text { Personal, special } \\
\text { biometric }\end{array}$ & $\begin{array}{l}\text { Personal and } \\
\text { sensitive }\end{array}$ & Personal & $\begin{array}{l}\text { Personal } \\
\text { special }\end{array}$ \\
\hline Database & \multicolumn{5}{|c|}{ Electronic and physical } \\
\hline
\end{tabular}

Source: Authors.

In Table 7 the law for personal data protection is presented for all countries of the BRICS. Although there are slight differences in the categories of data in the legislation of the countries, the content and treatment of the data are similar. Personal data such as name, age and documentation so that they can be processed and changed require the consent or communication of the holder, depending on the operation. The strictness of protection increases if the data is in the sensitive or special category. These are those that store information about racial or ethnic origin, religious belief, political opinion, union membership or organization of a religious, philosophical, or political character. In addition to data related to health or sexual option and biometric data.

After evaluating the literature contributions to the DGSOO theme and the legal aspects involving each BRICS country, Brazil is identified as a promising country for this type of service by specialists working in this area.

Some pillars qualify Brazil as an offshore outsourcing destination, being an IT sector with business knowledge, qualified human resources, extensive infrastructure, government support, favorable economy, political and legal environment, cultural compatibility and proximity to Brazil's time zone with countries like the United States and Europe (Prikladnicki, Carmel, 2014).

\subsection{Consultation with IT specialists}

In the data collection process, 41 questionnaires were obtained, obtained from 18 IT professionals and 23 researchers. However, only 19 questionnaires were considered in the analysis due to full information. In the first stage of data analysis, the objective was to identify the profile of respondents and their companies from (Figure 2). 
Figure 2. Analysis of demographic data.

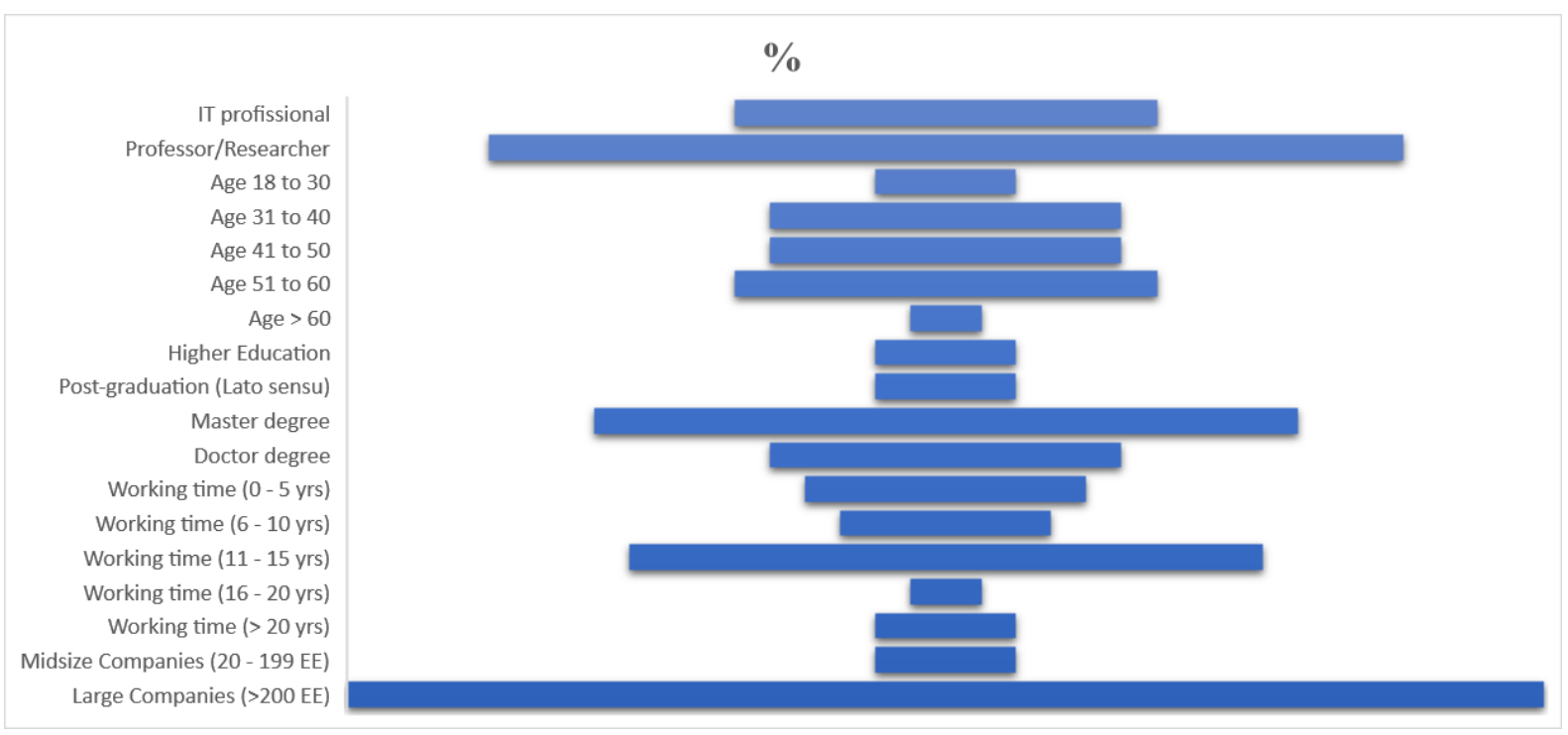

Source: Authors.

The analysis of demographic data from professional that work with software development is presented in Figure 2. The majority of the data were presented by professional that work in large companies.

Six institutions operate offshore outsourcing and among these, four in countries other than their headquarters. $94.7 \%$ of the institutions are headquartered in Brazil and 5.3\% in the USA. The main segments in which software projects are developed in these 6 institutions are finance, services, government, and manufacturing.

In the second stage of the analysis, data on property protection were analyzed (Figures 2 and 3 ).

Figure 3. Summary of information on DSGOO and the processing of personal data.

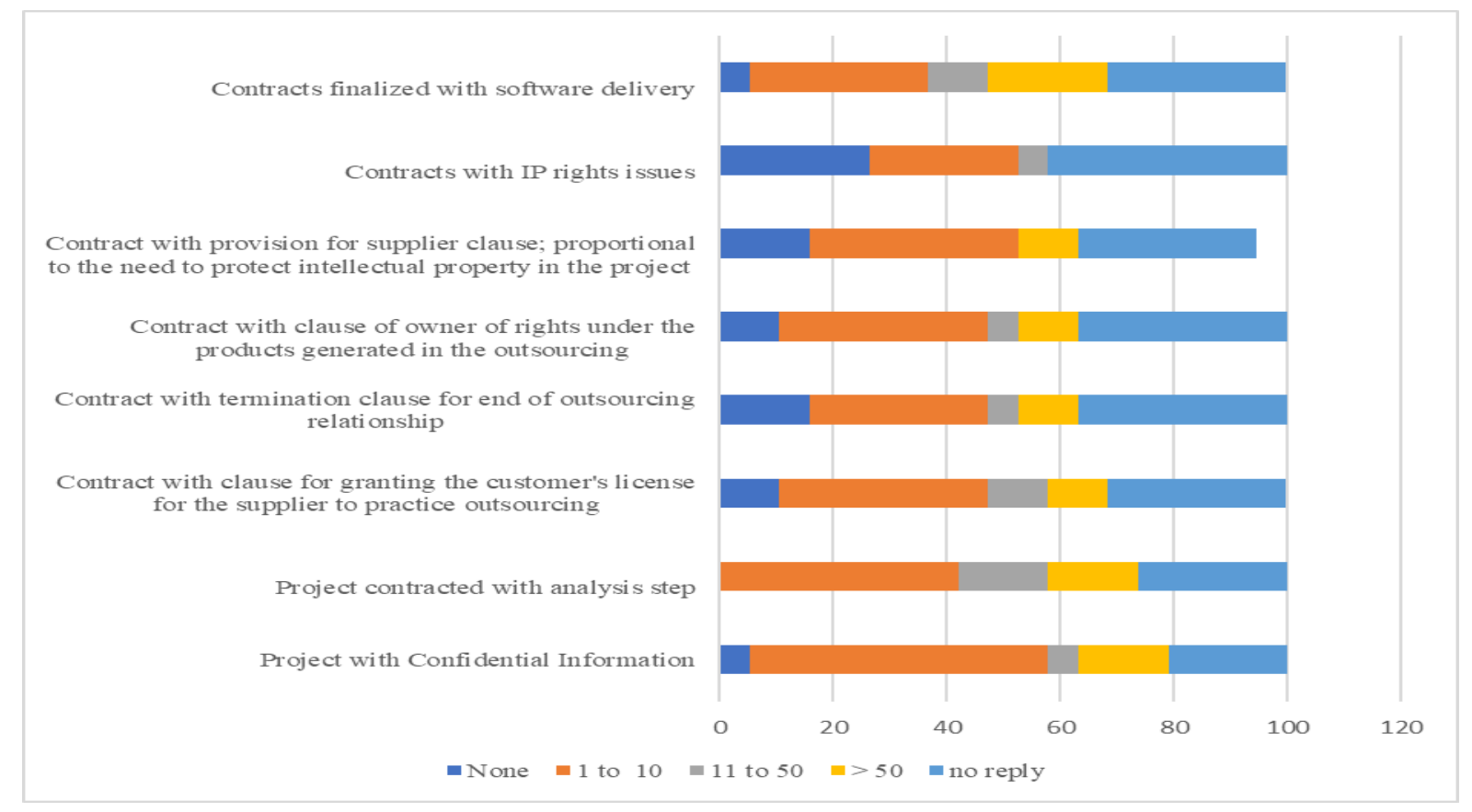

Source: Authors.

In Figure 3 are presented the information on DSGOO about contracts and projects. The institutions use a 
confidentiality agreement for the software design, team and data protection regulations, such as complying with the principle of transparency in data processing (Figure 4). However, most companies partially adopt the information security policy, which is the document that establishes the company's commitment to the protection of information, physical and software assets owned and / or under its custody. This action is important because it preserves confidentiality, integrity, authenticity, availability, and non-retractability (ABNT, 2013). The business continuity plan should also be considered, which guarantees the recovery of DGS environments from events that suspend its operations and components such as processes, people, software, hardware, infrastructure, information and intellectual property.

Figure 4. Summary of information on DSGOO and the processing of personal data.

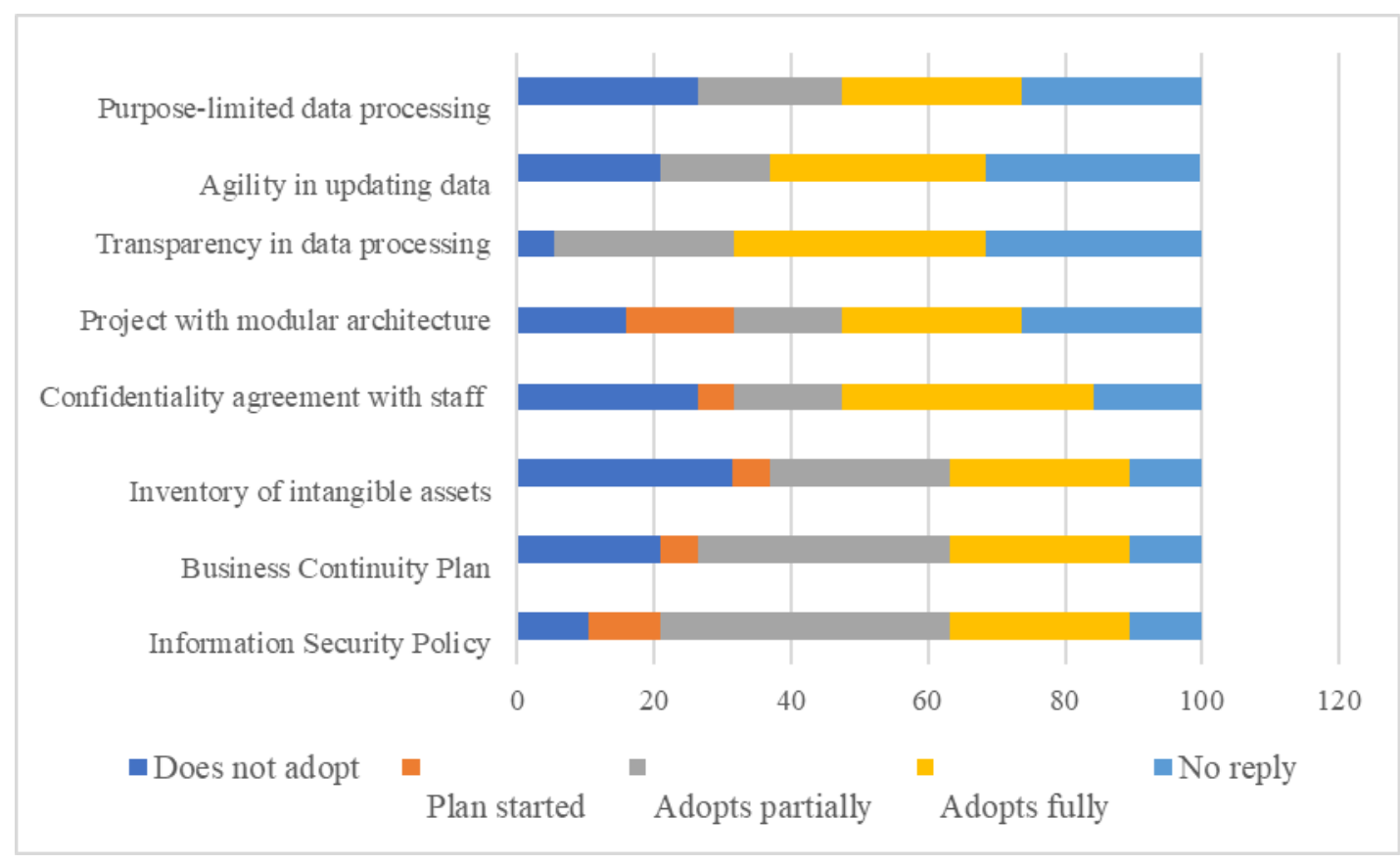

Source: Authors.

In Figure 4 are presented information how the companies lead with the data transparency, projects, confidentiality agreement and intangible assets. The greatest occurrences were found for the capacity to develop DGSOO projects and contracts, evidenced by the percentage of contracts finalized with delivery. Most contracts cover intellectual property clauses. The projects are mostly contracted in the software analysis stage and with confidential information. $26.3 \%$ of DGSOO contracts have problems with 1 to 10 projects per year. 5.3\% have problems in 11 to 50 projects per year. As for the number of employees who receive IP training in companies, on IP legislation (copyright, software, industrial secrecy, data protection); and regarding the company's and client's code of conduct, $47.4 \%$ train 1 to 50 employees, $21.0 \%$ do not train employees, $15.8 \%$ more than 200 employees and $15.8 \%$ did not respond.

\section{Conclusion}

Due to the ubiquitous nature of software in today's business environment, a DGSOO project needs to have its intellectual property protected, so that the risks of failure are minimized and the benefits achieved.

It was found that there is a need to develop a management model for environments that practice DGSOO. The model must be qualitative and quantitative, incorporating the use of indicators in the generation in the IPR certification. The role of the indicators in is to establish dimensions and phases involved in the process allowing the monitoring by the parties involved 
and feeding the decision-making process. The IP evaluation perspective should be considered, as a result that is determined at a certain moment or under a certain operational environment.

This work can contribute to define actions and checkpoints in the relationships between DSGOO service providers and client.

The focus is to establish in future studies a management model with practices, actions and risks related to IPR, which must be managed in each of the stages, mainly in the choice of the company and in the contract.

\section{Acknowledgment}

This study was financed in part by the Coordination for the Improvement of Higher Education Personnel - Brazil.

\section{References}

Benachenhou, A. (2013). Países emergentes. Fundação Alexandre de Gusmão. Available in:

Bookhamer, P., \& Zhang, Z. J. (2016). Knowledge management in a global context: a case study. Information Resources Management Journal (IRMJ), 29(1), 57-74. DOI: https://doi.org/10.1080/095373299107401

Brasscom (2018). Associação Brasileira de Empresas de Tecnologia da Informação e Comunicação. < https://brasscom.org.br/

Casey, V. (2008). Software Testing and Global Industry: Future Paradigms, In: Ita Richardson, Mícheál ÓhAodha (Eds.), Cambridge Scholars Publishing. https://books.google.com.br/bo oks?id=7ILBwAAQBAJ\&lpg=PR7\&ots=yaPYwxsuo2\&dq=Software\%20Testing\%20and\%20Global\%20Industry\%3 A $\% 20$ Future $\% 20$ Paradigms\&lr\&hl=ptBR\&pg=PP1\#v=onepage \&q=Software $\% 20$ Testing $\% 20$ and $\% 20$ Global\%20Industry:\%20Future $\% 20$ Paradigms\&f=false

Doh, J. P. (2005). Offshore outsourcing: Implications for international business and strategic management theory and practice. Journal of Management Studies, 42(3), 695-704. https://doi.org/10.1111/j.1467-6486.2005.00515.x

Doh, J., Bunyaratavej, K., \& Hahn, E. (2009). Separable but not equal: The location determinants of discrete services offshoring activities. Journal of International Business Studies, 40, 926-943. https://doi.org/10.1057/jibs.2008.89

Gupta RS (2018). Risk Management and Intellectual Property Protection in Outsourcing. Global Business Review, 19(2):393-406. https://doi.org/10.1177/0972150917713536

Henkel, J., Baldwin, C. Y., \& Shih, W. (2012). IP Modularity: Profiting from Innovation by Aligning Product Architecture with Intellectual Property. Harvard Business School Finance, Harvard Business School Technology \& Operations Mgt. Unit Working Paper No. 13-012. <https://ssrn.com/abstract=2121600>, http://dx.doi.org/10.2139/ssrn.2121600

Ipbrics, http://www.ipbrics.org.

Jandhyala, S. (2013). Property rights and international investment in information technology services. Strategic Management Journal, 34(7), 877-889. https://doi.org/10.1002/smj.2032

Jennex, M. E., \& Adelakun, O. (2003). Success factors for offshore information system development. Journal of Information Technology Case and Application Research, 5(3), 12-31. https://doi.org/10.1080/15228053.2003.10856024

Jones, W. O. (2009). Outsourcing in China: opportunities, challenges and lessons learned: INDUSTRY INSIGHT. Strategic Outsourcing: An International Journal, 2 (2), 187-203. https://doi.org/10.1108/17538290910973385

Kearney, A. T. (2007). Global services location index. <https://www.kearney.com/digital-transformation/gsli/2019-full-report.>

Khan, S. U., Niazi, M., \& Ahmad, R. (2011). Barriers in the selection of offshore software development outsourcing vendors: An exploratory study using a systematic literature review, Information and Software Technology, 53(7), 693-706. https://doi.org/10.1016/j.infsof.2010.08.003.

Lewin, A., Massini, S., \& Peeters, C. (2009). Why are companies offshoring innovation? The emerging global race for talent. Journal of International Business Studies, 40, 901-925. https://doi.org/10.1057/jibs.2008.92

Mahmoodm N., Mahmood, S., Alshayebm, M., Riaz, M. R., Faisal. K., Cerpa, N., Khan, S. U., \& Richardson, I. (2016). Challenges of project management in global software development: A client-vendor analysis. Information and Software Technology, 80, 1-19. https://doi.org/10.1016/j.infsof.2016.08.002.

Manteli, C., Van Den Hooff, B., \& Van Vliet, H. (2014). The effect of governance on global software development: An empirical research in transactive memory systems. Information and Software Technology, 56(10), 1309-1321. https://doi.org/10.1016/j.infsof.2014.04.012

Mathurm J. D., \& Khurana, R. (2013). Need for sustainable global business model in software outsourcing: The Indian perspective. Business Process Management Journal, 19(1), 54-69. https://doi.org/10.1108/14637151311294868

Pai, A. K., \& Basu, S. (2007). Offshore technology outsourcing: overview of management and legal issues. Business Process Management Journal, 13(1), 2146. https://doi.org/10.1108/14637150710721113

Parviainen, P., \& Tihinen, M. (2014). Knowledge-related challenges and solutions in GSD. Expert Systems, 31(3), 253-266. https://doi.org/10.1111/exsy.608 
Prikladnicki, R., \& Carmel, E. (2014). The Emerging Brazilian I.T. Industry and its Time-Zone Proximity Advantage. Journal of Global Information Management (JGIM), 22(1), 1-13. https://ideas.repec.org/a/igg/jgim00/v22y2014i1p1-13.html

Ranganathan, C., \& Balaji, S. (2007). Critical Capabilities for Offshore Outsourcing of Information Systems. MIS Q. Executive, 6. http://www.indianjournals.com/ijor.aspx?target=ijor:ijemr\&volume=8\&issue=1\&article $=014$

Representante, P, Brasil, B. A. K. E. R. T. I. L. L. Y., Thomé, A, Farias Jr, CA, Experian, S, Menoncello, D, \& Brasileiro, V (2013). Tecnologia da Informação-Técnicas de Segurança-Código de Prática para controles de segurança da informação. <http://professor.ufabc.edu.br/ joao.kleinschmidt/aulas/seg2018-2Q/norma2.pdf>

Samantra, C., Datta, S., \& Mahapatra, S. S. (2014). Risk assessment in IT outsourcing using fuzzy decision-making approach: An Indian perspective. Expert Systems with Applications, 41(8), 4010-4022. https://doi.org/10.1016/j.eswa.2013.12.024.

Serviço De Publicações Da EU. Regulamento Geral de Proteção de Dados da EU N ${ }^{o}$ 679/2016. https://publications.europa.eu/pt/publication-detail//publication/3e485e15-11bd-11e6-ba9a-01aa75ed71a1>

Søderberg, A-M., \& Romani, L. (2017). Boundary Spanners in Global Partnerships: A Case Study of an Indian Vendor's Collaboration With Western Clients. Group \& Organization Management, 42(2), 237-278. https://doi.org/10.1177/1059601117696618

Sudhakar, G. P. (2013). A Review of Critical Success Factors for Offshore Software Development Projects. Organizacija, 46(6), 282-296. https://doi.org/10.2478/orga-2013-0026

Verner, J. M., Brereton, O. P., Kitchenham, B. A., Turner, M., \& Niazi, M. (2014). Risks and risk mitigation in global software development: A tertiary study. Information and Software Technology, 56(1), 54-78. http://dx.doi.org/10.1016/j.infsof.2013.06.005

Wiederhold, G., Gupta, A., \& Neuhold, E. (2010). Offshoring and transfer of intellectual property. Information Resources Management Journal (IRMJ), 23(1), 74-93. http://dx.doi.org/10.4018/IRMJ

Wipo (2018) World Intellectual Property Organization. Introdução a Propriedade Intelectual (Modulo 2 Curso DL101PBR). <https://www.wipo.org>.

Zaheer, S., Lamin, A., \& Subramani, M. (2009). Cluster capabilities or ethnic ties? Location choice by foreign and domestic entrants in the services offshoring industry in India. Journal of International Business Studies, 40(6), 944-968. https://doi.org/10.1057/jibs.2008.91 